\title{
Pengaruh Konservatisme, Dividend Payout Ratio, Tingkat Likuiditas Aset, dan Leverage Terhadap Harga Saham Pada Perusahaan Manufaktur
}

\section{ANDREAS R. WANGARRY ${ }^{1}$, HERMAN KARAMOY ${ }^{2}$, HENDRIK GAMALIEL ${ }^{3}$}

\author{
${ }^{1,2,3}$ Program Studi Magister Akuntansi, Fakultas Ekonomi dan Bisnis Universitas Sam Ratulangi

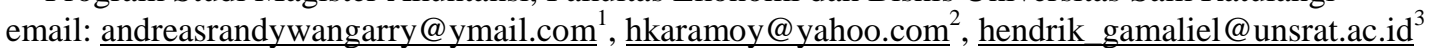

\begin{abstract}
This study aims to examine the effect of conservatism, dividend payout ratio, level of asset liquidity, and leverage on the stock prices of manufacturing companies. This study employed secondary data in the form of financial statements of manufacturing companies from 2013-2017. 106 manufacture companies were chosen as samples and the number of observations were 530. The analytical method used in this study was multiple linear regression. The results showed partially, conservatism and dividend payout ratio had a significant effect on the stock price of manufacturing companies, while the variable level of asset liquidity and leverage did not significantly influence the stock price of manufacturing companies.
\end{abstract}

Keywords: conservatism, dividend payout ratio, level of asset liquidity, leverage, and stock price.

Abstrak. Penelitian ini bertujuan untuk menguji pengaruh konservatisme, dividend payout ratio, tingkat likuiditas aset, dan leverage terhadap harga saham perusahaan manufaktur. Dalam penelitian ini menggunakan data sekunder berupa laporan keuangan perusahaan manufaktur dari tahun 2013-2017. Sampel dalam penelitian ini sebanyak 106 sampel perusahaan dan jumlah pengamatan atau observasi sebanyak 530. Metode analisis yang digunakan dalam penelitian ini adalah regresi linear berganda. Hasil penelitian menunjukkan secara parsial, variabel konservatisme dan dividend payout ratio berpengaruh signifikan terhadap harga saham perusahaan manufaktur, sedangkan variabel tingkat likuiditas aset dan leverage tidak berpengaruh signifikan terhadap harga saham perusahaan manufaktur.

Kata kunci: konservatisme, dividend payout ratio, tingkat likuiditas aset, leverage, dan harga saham.

\section{Pendahuluan}

Dalam berinvestasi, banyak faktor yang menjadikan dasar pemikiran para calon investor untuk mengambil keputusan, apakah akan berinvestasi atau tidak dan seberapa besar dana yang akan diinvestasikan pada perusahaan tersebut, sehingga calon investor mau melakukan berbagai cara agar dana yang diinvestasikan tersebut mendapatkan return yang maksimal. Dalam mengamati harga saham, terdapat analisis fundamental yang dapat menjadi tolak ukur bagi investor dalam melihat pergerakan harga saham dari perusahaan ataupun dapat menjadi patokan bagi calon investor dalam memilih saham perusahaan mana yang akan dibeli. Perusahaan-perusahaan yang sudah go public yang terdaftar di BEI pasti berusaha dalam menjalankan kegiatan operasionalnya dan mempertahankan kinerja yang baik serta berusaha memperoleh laba guna menarik minat para investor. Para investor kini mulai melirik perusahaan manufaktur di Indonesia karena laju pertumbuhan pada sektor ini melaju cukup pesat.

Dalam mengambil keputusan untuk membeli saham perusahaan (investasi), para calon investor pasti akan mencari info yang terperinci terlebih dahulu terhadap perusahaan yang akan di investasikan. Oleh karena itu, perusahaan-perusahaan biasanya akan memberi sinyal kepada para calon investor tentang kondisi atau keadaan perusahaan tersebut. Kondisi ini sejalan dengan Signaling Theory atau teori pensinyalan dikembangkan oleh Ross (1977), yang menyatakan bahwa pihak eksekutif perusahaan memiliki informasi yang lebih baik mengenai perusahaannya akan terdorong untuk menyampaikan informasi tersebut kepada calon investor agar harga saham perusahaannya meningkat. Informasi yang diberikan oleh perusahaan akan di respon langsung oleh pasar sebagai sinyal good news atau bad news, sehingga sinyal yang diberikan oleh perusahaan dapat diterima dan diharapkan pasar dapat membedakan perusahaan yang berkualitas baik dan buruk. Teori pensinyalan bermanfaat untuk mengukur akurasi dan ketepatan waktu perusahaan dalam melakukan pelaporan keuangan ke publik.

Dalam pembuatan laporan keuangan dikenal sebuah konsep yang dinamakan konservatisme. Secara umum, konservatisme dikatakan sebagai sebuah prinsip yang mengakui biaya atau beban terlebih dahulu dan pendapatan di belakang. Konservatisme sering dikatakan sebagai 
prinsip yang pesimis dikarenakan pendapatan yang diakui belakangan daripada beban. Namun ada juga yang mengatakan konservatisme sebagai prinsip yang membantu perusahaan untuk mengantisipasi agar tidak terlalu optimis, dikarenakan setiap spekulasi perusahaan tidak selalu dapat berjalan lancar. Roda perekonomian yang tidak pasti membuat prinsip konservatisme sebagai salah satu pegangan dalam akuntansi.

Dalam penelitian yang dilakukan oleh Susanto dan Ramadhani (2016), menyatakan bahwa informasi laba akan membantu investor dan kreditor dalam mebgevaluasi kinerja perusahaan, memprediksi laba di masa akan dating, dan juga memperhitungkan risiko investasi atau pinjaman kepada perusahaan. Profit atau laba yang didapat perusahaan sehingga dengan adanya profit tersebut, maka biasanya perusahaan akan membagi keuntungan kepada para pemegang saham lewat pembagian dividen. Dengan profit yang didapat perusahaan tersebut serta adanya pembagian dividen yang dilakukan perusahaan, maka hal ini juga bisa membuat harga saham perusahaan tersebut menjadi naik. Perusahaan biasanya akan membagi dividen kepada para investor (pemegang saham) jika perusahaan tersebut mendapatkan profit atau laba. Brigham dan Houston (2009) menyatakan bahwa semakin tinggi tingkat dividen yang dibayarkan, berarti semakin sedikit laba yang ditahan dan sebagai akibatnya ialah menghambat tingkat pertumbuhan dalam pendapatan tetapi harga sahamnya akan meningkat karena para investor berpikir akan mendapatkan dividen.

Selain dengan pengumuman pembagian dividen, perusahaan juga dapat memberikan sinyal kepada para investor untuk tidak mengosongkan portofolionya melalui informasi tentang keadaan perusahaan tersebut apakah dalam keadaan yang baik sehingga investor tidak akan memiliki keraguan terhadap prospek pertumbuhan dan perkembangan perusahaan di masa sekarang dan masa yang akan datang. Informasi tersebut dapat berupa likuiditas dari perusahaan yang dapat dilihat melalui nilai perusahaan tersebut. Likuiditas merupakan salah satu faktor yang dapat mempengaruhi nilai perusahaan. Nilai perusahaan dapat menjadi faktor yang dipertimbangkan oleh para investor dalam mengambil keputusan. Nilai perusahaan merupakan indikator kinerja keuangan bagi perusahaan yang go public. Dengan likuiditas aset yang tinggi, maka semakin besar kemampuan perusahaan untuk memenuhi kewajiban jangka pendeknya (Kusumadewi dan Sudiartha, 2016).

Adanya aset yang tidak likuid dapat membuat perusahaan kesulitan untuk memenuhi kewajiban jangka pendeknya serta pendanaan kegiatan operasional, sehingga perusahaan tersebut akan condong untuk melakukan pinjaman (hutang) guna menjadi pemenuhan dana perusahaan dalam menjalankan kegiatan operasionalnya.

Penggunaan hutang untuk memenuhi kebutuhan dana perusahaan akan menghasilkan keuntungan dan dapat berdampak pada kerugian yang tidak lain adalah merupakan risiko dari penggunaan hutang. Hutang menyebabkan beban yang bersifat tetap yaitu beban bunga dan pokok pinjaman yang harus dibayar.

Berdasarkan latar belakang di atas maka penulis merumuskan masalah penelitian sebagai berikut.

1. Apakah konservatisme berpengaruh terhadap harga saham?

2. Apakah dividend payout ratio (DPR) berpengaruh terhadap harga saham?

3. Apakah tingkat likuiditas aset berpengaruh terhadap harga saham?

4. Apakah leverage berpengaruh terhadap harga saham?

Tujuan yang hendak dicapai dalam penelitian ini adalah untuk menguji dan memperoleh hasil empiris semua rumusan masalah yang ada. Manfaat yang diharapkan dalam penelitian ini adalah pengembangan penelitian bidang akuntansi keuangan berbasis data pasar modal, yang diharapkan dapat memberikan kontribusi sebagai bahan masukan dan pertimbangan dalam pengambilan kebijakan dan keputusan terkait investasi saham. Bagi dunia pendidikan, hasil penelitian ini diharapkan dapat menjadi bahan kajian dan pengujian terhadap faktor-faktor yang dapat mempengaruhi harga saham perusahaan manufaktur yang terdaftar di BEI.

\section{Tinjauan Pustaka}

\section{Teori Pensinyalan (Signaling Theory)}

Signalling Theory atau teori pensinyalan dikembangkan oleh Ross (1977), yang menyatakan bahwa pihak eksekutif perusahaan memiliki informasi lebih baik mengenai perusahaannya akan terdorong untuk menyampaikan informasi tersebut kepada calon investor agar harga saham perusahaannya meningkat. Hal positif dalam signalling theory dimana perusahaan yang memberikan informasi yang bagus akan membedakan mereka dengan perusahaan yang tidak memiliki "berita bagus" dengan menginformasikan pada pasar tentang keadaan mereka, sinyal tentang bagusnya kinerja masa depan yang diberikan oleh perusahaan yang kinerja keuangan masa lalunya tidak bagus tidak 
akan dipercaya oleh pasar. Godfrey et al. (2006) dalam En dan Rusli (2011) mengatakan teori sinyal berbicara mengenai manajer yang menggunakan akun-akun dalam laporan keuangan untuk memberikan tanda atau signal harapan dan tujuan masa depan.

\section{Teori Keagenan (Agency Theory)}

Masalah keagenan (agency problem) pada awalnya dieksplorasi oleh Ross (1973), sedangkan eksplorasi teoritis secara mendetail dari teori keagenan pertama kali dinyatakan oleh Jensen and Meckling (1976) menyebutkan manajer suatu perusahaan sebagai "agen" dan pemegang saham sebagai "principal". Pemegang saham yang merupakan principal mendelegasikan pengambilan keputusan bisnis kepada manajer yang merupakan perwakilan atau agen dari pemegang saham. Dalam penelitian ini, variabel-variabel independen yang terkait dengan teori keagenan ini adalah variabel konservatisme, dividend payout ratio, tingkat likuiditas aset, dan leverage. Manajer sebagai agent, "ditugaskan" oleh para pemegang saham selaku principal guna menjalankan perusahaan tersebut beserta pengambilan keputusan-keputusan bisnis yang harus diambil oleh manajer sehingga dapat meningkatkan performa perusahaan dan mampu menghasilkan laba.

\section{Teori Efficiency Market Hypotesis (EMH)}

Teori EMH yang diperkenalkan oleh Fama (1970), menjadi teori yang cukup populer dan banyak dijadikan sebagai dasar dalam berbagai penelitian mengenai anomali pasar belakangan ini. Fama mengemukakan bahwa dalam suatu pasar yang efisien, harga akan "mencerminkan sepenuhnya" informasi yang tersedia dan sebagai implikasinya harga akan bereaksi seketika tanpa adanya bias terhadap informasi baru. Teori Efficiency Market Hypotesis ini terkait dengan variabel dependen dalam penelitian ini, yaitu harga saham, dan juga dengan variabel independen, yaitu variabel dividend payout ratio, tingkat likuiditas aset, dan leverage. Dalam pasar modal, harga saham suatu perusahaan pasti akan mencerminkan atau menggambarkan keadaan suatu perusahaan.

\section{Konservatisme}

Givoly dan Hayn (2002) mendefinisikan konservatisme sebagai pengakuan awal untuk biaya dan rugi serta menunda pengakuan untuk pendapatan dan keuntungan. Konservatisme diukur dengan menggunakan pendekatan net asset measures yang menggunakan market to book ratio, yaitu dengan mengalikan jumlah saham beredar dan harga penutupan saham kemudian dibagi dengan total ekuitas. Market to book ratio mengindikasikan pandangan investor terhadap nilai perusahaan. Perusahaan yang dipandang baik dan bagus, sahamnya akan dijual lebih tinggi dibandingkan nilai bukunya. Menurut Gitman (2009), market to book ratio (MtB) merupakan rasio perbandingan antara harga pasar per lembar saham dibandingkan dengan nilai bukunya.

\section{Dividend Payout Ratio (DPR)}

DPR menunjukkan besaran dividen yang dibagikan terhadap total laba bersih perusahaan sekaligus menjadi sebuah parameter untuk mengukur besaran dividen yang akan dibagikan ke pemegang saham (Hery, 2015: 209). Semakin besar laba yang diperoleh perusahaan, maka semakin besar dividen yang dibayarkan, demikian pula sebaliknya bila laba kecil maka dividen yang dibayarkan juga kecil (Sutrisno, 2009: 269). Jumlah yang tidak dibayarkan dalam dividen kepada pemegang saham dipegang oleh perusahaan untuk mengembangkan perusahaan. Jumlah yang disimpan oleh perusahaan disebut saldo laba ditahan. DPR dihitung dengan membagi total dividen dengan laba bersih perusahaan.

\section{Likuiditas Aset}

Likuiditas aset seringkali hanya disebut dengan kata likuiditas, yang didefinisikan sebagai kemampuan perusahaan dalam memenuhi kewajiban jangka pendeknya dengan aset atau harta lancarnya. Munawir (2002:31) mengatakan bahwa likuiditas menunjukkan kemampuan suatu perusahaan untuk memenuhi kewajiban keuangannya yang harus dipenuhi atau kemampuan perusahaan unuk memenuhi kewajiban keuangannya pada saat ditagih. Perusahaan yang memiliki aset yang likuid sangat bermanfaat atau berguna bisa menjadi tambahan pendanaan bagi perusahaan dalam melaksanakan kegiatan operasionalnya. Tingkat likuiditas aset diukur dengan cara yakni kas dan setara kas dibagi dengan total aset perusahaan yang tercantum dalam laporan keuangan perusahaan. 


\section{Leverage}

Leverage adalah penggunaan aset dan sumber dana (source of funds) oleh perusahaan yang memiliki beban tetap dengan maksud agar meningkatkan keuntungan potensial pemegang saham (Sartono, 2008:257). Leverage adalah suatu tingkat kemampuan perusahaan dalam menggunakan aktiva dan atau dana yang mempunyai beban tetap (hutang dan atau saham istimewa) dalam rangka mewujudkan tujuan perusahaan untuk memaksimalkan kekayaan pemilik perusahaan. Rasio hutang atau leverage menunjukkan seberapa besar kebutuhan dana perusahaan dibelanjai dengan hutang. Apabila perusahaan tidak mempunyai leverage atau rasio leverage-nya bernilai nol, artinya perusahaan beroperasi sepenuhnya menggunakan modal sendiri tanpa menggunakan hutang (En dan Rusli. 2011). Leverage diukur dengan menggunakan proksi debt to equity ratio diukur dengan cara yakni total hutang dibagi total modal perusahaan yang tercantum dalam laporan keuangan tahunan perusahaan.

\section{Saham}

Semakin tinggi nilai perusahaan maka akan membuat harga saham perusahaan tersebut akan semakin tinggi karena dengan nilai perusahaan (firm value) yang tinggi akan menjadi sinyal dari perusahaan bagi para investor bahwa perusahaan dalam keadaan atau tren yang baik dan memberikan keyakinan kepada investor untuk membeli saham perusahaan tersebut dan dengan demikian membuat harga saham perusahaan tersebut akan naik. Proksi dari nilai perusahaan yang digunakan dalam penelitian ini adalah harga saham. Saham dapat didefinisikan sebagai tanda penyertaan atau kepemilikan seseorang atau badan dalam suatu perusahaan atau perseroan terbatas.

Perusahaan penerbit yang mampu menghasilkan laba yang besar maka ada kemungkinan para pemegang sahamnya akan menikmati keuntungan yang besar pula, karena laba yang besar tersebut menyediakan dana yang besar untuk didistribusikan kepada pemegang saham sebagai dividen. Tidak hanya dividen yang akan didapatkan oleh pemegang saham atau investor tetapi investor juga bisa mendapatkan capital gain. Capital gain adalah keuntungan dari hasil menjual atau membeli saham berupa kelebihan nilai jual dari nila beli saham (Falani, 2013). Pembelian kembali saham diyakini menyuntikkan beberapa pengaruh ke dalam harga saham sejak harga beli kembali ditetapkan pada tingkat yang lebih tinggi dari harga pasar yang berlaku, dengan demikian dianggap sebagai langkah penting untuk menyelamatkan pasar saham (Chatterjee, 2015).

\section{Gambar 1. Rerangka Konseptual Penelitian}

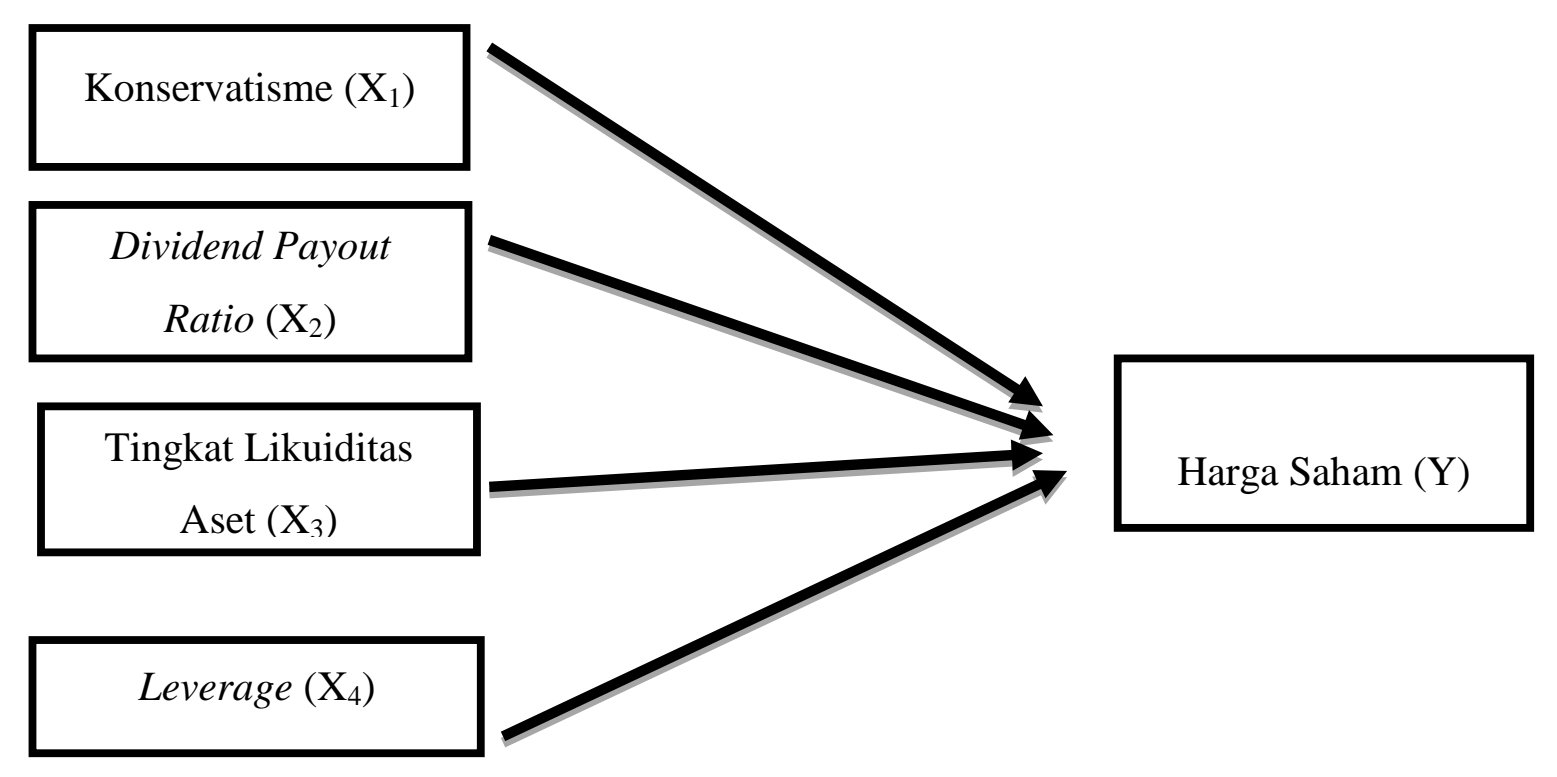

Berdasarkan landasan teori dan rerangka konseptual penelitian, maka persamaan regresi berganda dalam penelitian ini adalah sebagai berikut:

$$
Y=\alpha+\beta_{1} X_{1}+\beta_{2} X_{2}+\beta_{3} X_{3}+\beta_{4} X_{4}+E
$$


Dimana:

$$
\begin{aligned}
& Y=\text { Harga Saham } \\
& \alpha=\text { Konstanta } \\
& \beta_{1}, \beta_{2}, \beta_{3}, \beta_{4}=\text { Koefisiensi regresi variabel independen } \\
& \mathrm{X}_{1}=\text { Konservatisme } \\
& \mathrm{X}_{2}=\text { Dividend Payout Ratio } \\
& \mathrm{X}_{3}=\text { Tingkat Likuiditas Aset } \\
& \mathrm{X}_{4}=\text { Leverage }
\end{aligned}
$$

Sedangkan hipotesis dalam penelitian ini yang dirumuskan menjadi 4 hipotesis adalah sebagai berikut.

1. Pengaruh Konservatisme terhadap Harga Saham

Konservatisme dikatakan sebagai sebuah prinsip yang mengakui biaya atau beban terlebih dahulu dan pendapatan di belakang. Konservatisme sering dikatakan sebagai prinsip yang pesimis dikarenakan pendapatan yang diakui belakangan daripada beban. Namun terdapat juga yang mengatakan konservatisme sebagai prinsip yang membantu perusahaan untuk mengantisipasi agar tidak terlalu optimis, dikarenakan setiap spekulasi perusahaan tidak selalu dapat berjalan lancar. Roda perekonomian yang tidak pasti membuat prinsip konservatisme sebagai salah satu pegangan dalam akuntansi. Dalam melakukan investasi diperlukan pengetahuan untuk memahami dan menganalisis kinerja perusahaan melalui informasi yang disajikan pada laporan keuangan. Dengan laporan keuangan yang baik dan audit report yang cepat, maka perusahaan dapat memberikan sinyal atau berita bagus kepada para calon investor maupun para investor yang sudah membeli saham perusahaan tersebut. Hal ini sejalan dengan teori pensinyalan (Signaling Theory), dimana perusahaan memberikan sinyal kepada pihak di luar perusahaan. Dalam penelitian sebelumnya yang dilakukan Tuwentina dan Wirama (2014) menyatakan bahwa konservatisme berpengaruh positif terhadap harga saham. Penelitian sebelumnya yang lain yang dilakukan oleh Novalia dan Nindito (2016) menyatakan bahwa konservatisme berpengaruh signifikan terhadap harga saham.

$\mathrm{H}_{1}$ : Konservatisme berpengaruh terhadap harga saham perusahaan yang terdaftar di BEI.

\section{Pengaruh Dividend Payout Ratio (DPR) terhadap Harga Saham}

Sinyal yang berupa good news yakni informasi profit atau laba yang didapat perusahaan sehingga dengan adanya profit tersebut, maka biasanya perusahaan akan membagi keuntungan kepada para pemegang saham lewat pembagian dividen. Dengan profit yang didapat perusahaan tersebut serta adanya pembagian dividen yang dilakukan perusahaan, maka hal ini juga bisa membuat harga saham perusahaan tersebut menjadi naik. Dividend Payout Ratio $(D P R)$ yaitu rasio yang menentukan jumlah laba yang dapat ditahan sebagai sumber pendanaan serta menunjukkan persentase laba perusahaan yang dibayarkan ke pemegang saham dalam bentuk kas atau pembagian saham. Dalam penelitian yang dilakukan Wijaya dan Suarjaya (2017) menyatakan bahwa dividend payout ratio berpangaruh positif dan signifikan terhadap harga saham perusahaan. Pada penelitian sebelumnya yang lainnya yang dilakukan oleh Nugraha dan Sudaryanto (2016) menyatakan bahwa dividend payout ratio memiliki hubungan positif dan berpengaruh secara signifikan terhadap harga saham.

$\mathrm{H}_{2}$ : Dividend Payout Ratio berpengaruh terhadap harga saham perusahaan yang terdaftar di BEI.

\section{Pengaruh Tingkat Likuiditas Aset terhadap Harga Saham}

Perusahaan yang memiliki aset yang likuid sangat bermanfaat atau berguna bisa menjadi tambahan pendanaan bagi perusahaan dalam melaksanakan kegiatan operasionalnya. Dengan aset yang likuid juga dapat menekan penggunaan biaya modal dan risiko dalam perusahaan karena adanya manfaat dari aset tersebut yang bisa digunakan atau di manfaatkan dibandingkan dengan aset yang tidak likuid. Risiko yang rendah yang dihadapi perusahaan bisa menunjang performa perusahaan untuk berada dalam keadaan yang baik serta meningkatkan nilai perusahaan. Nilai perusahaan yang meningkat otomatis akan menjadi sinyal positif bagi para investor untuk membeli saham perusahaan tersebut karena hal tersebut menjadi sinyal bahwa perusahaan dalam keadaan yang baik. Dengan begitu maka akan 
membuat harga saham perusahaan tersebut juga akan meningkat atau mengalami kenaikan harga saham. Dalam penelitian yang dilakukan oleh Anjarwati (2016) menyatakan bahwa likuiditas memiliki pengaruh terhadap nilai perusahaan dengan di mediasi struktur modal.

H3: Tingkat Likuiditas Aset berpengaruh terhadap harga saham perusahaan yang terdaftar di BEI.

\section{Pengaruh Leverage terhadap Harga Saham}

Leverage dapat menggambarkan sumber pendanaan perusahaan yang berasal dari hutang yang akan berakibat pada reaksi pasar saham, volume perdagangan saham dan harga saham. Dengan rasio hutang yang tinggi menunjukkan tingkat hutang perusahaan yang tinggi pula sehingga mengakibatkan sebagian investor takut dalam berspekulasi dalam penanaman sahamnya ke perusahaan tersebut. Dengan tingkat hutang yang tinggi akan menjadi beban atau ancaman bagi perusahaan jika tidak dapat menyeimbangkannya dengan keuntungan, sehingga itu dapat membuat perusahaan kesulitan untuk membagi dividen kepada para pemegang saham dikarenakan profit yang didapat hanya sedikit ataupun perusahaan mengalami kerugian dalam tahun berjalan. Hal tersebut dapat menjadi sinyal bad news kepada pihak luar perusahaan yang mengetahui kondisi yang kurang baik sedang dialami perusahaan. Dalam penelitian yang dilakukan oleh Gursida (2015) menyatakan bahwa leverage dengan proksi debt to equity ratio (DER) berpengaruh signifikan terhadap harga saham. Pada penelitian lainnya yang dilakukan oleh Ernawati, Dewi, dan Widyawati (2015) menyatakan bahwa leverage berpengaruh positif terhadap harga saham.

H4: Leverage berpengaruh terhadap harga saham perusahaan yang terdaftar di BEI.

\section{Metode Penelitian \\ Jenis Penelitian}

Penelitian ini menggunakan metode kuantitatif. Peneliti menggunakan metode kuantitatif karena dalam penelitian ini akan menguji hipotesis dengan menggunakan analisis regresi linear berganda dan akan menjelaskan fenomena dalam bentuk hubungan antar variabel yakni variabel independen dengan variabel dependen.

\section{Populasi dan Sampel}

Populasi dalam penelitian ini adalah perusahaan manufaktur yang sudah terdaftar (listing) di Bursa Efek Indonesia (BEI) yaitu sebanyak 144 emiten perusahaan manufaktur. Pemilihan sampel dalam penelitian ini menggunakan metode purposive sampling, yang merupakan metode penelitian sampel yang didasarkan pada beberapa kriteria-kriteria tertentu, meliputi:

1. Perusahaan manufaktur yang terdaftar di BEI tahun 2013 sampai dengan tahun 2017.

2. Perusahaan manufaktur yang tidak di delisting di BEI tahun 2013 sampai dengan tahun 2017.

3. Perusahaan manufaktur yang mempublikasikan laporan keuangan dengan lengkap di BEI tahun 2013 sampai dengan tahun 2017.

Jumlah sampel yang digunakan dalam penelitian ini sebanyak 106 perusahaan manufaktur yang terdiri dari 3 sektor dan 18 sub sektor perusahaan dengan periode pengamatan selama 5 tahun, dari tahun 2013 sampai dengan tahun 2017, sehingga jumlah pengamatan atau observasi dalam penelitian ini adalah sebanyak 530 .

\section{Metode Pengumpulan Data}

Teknik yang digunakan dalam pengumpulan data untuk penelitian ini adalah dengan dokumentasi, yaitu dengan mengumpulkan semua data sekunder yang dipublikasikan oleh Bursa Efek Indonesia (BEI) tentang laporan keuangan perusahaan-perusahaan manufaktur yang sudah terdaftar.

\section{Metode Analisis}

1. Pengujian Asumsi Klasik

Dalam penelitian ini digunakan pengujian asumsi klasik yang terdiri dari beberapa jenis pengujian yakni sebagai berikut.

a. Uji Normalitas

Uji asumsi ini akan menguji data variabel bebas dan data variabel terikat pada persamaan regresi yang dihasilkan, apakah berdistribusi normal atau berdistribusi tidak normal. 
Persamaan regresi dikatakan baik jika mempunyai data variabel bebas dan data variabel terikat berdistribusi mendekati normal atau normal sama sekali.

b. Uji Heteroskedastisitas

Uji heretoskedastisitas bertujuan untuk melihat apakah dalam model regresi terjadi ketidaksamaan variabel dari satu pengamatan ke pengamatan lain regresi ini. Jika varians dari satu pengamatan itu adalah tetap maka homokedastisitas dan jika varians berbeda maka terjadi heteroskedastisitas. Pada pengujian ini menggunakan uji Park.

c. Uji Multikolinearitas

Analisis multikolinearitas diterapkan untuk analisis regresi berganda yang terdiri atas dua atau lebih variabel bebas, dimana akan diukur tingkat asosiasi (keeratan) hubungan atau pengaruh antar variabel bebas tersebut melalui besaran koefisien korelasi (Sunyoto 2012: 79). Jika terjadi korelasi maka terdapat masalah multikolinearitas shingga model regresi tidak dapat digunakan. Dalam penelitian ini Multikolinearitas dapat dideteksi dengan melihat nilai tolerance $(\alpha)$ lebih dari 0,10 dan Variance Inflation Factor (VIF) kurang dari 10.

\section{Pengujian Hipotesis}

Dalam penelitian ini digunakan pengujian hipotesis untuk menguji hipotesis yang ada. Jenis pengujian hipotesis yang digunakan dalam penelitian ini yakni dengan melakukan uji t (uji parsial). Uji t dilakukan untuk mengetahui pengaruh setiap variabel-variabel independen dan variabel intervening terhadap variabel dependen. Penelitian ini menggunakan tingkat signifikan $(\alpha)$ sebesar 5\% untuk membandingkan thitung dengan $\mathrm{t}$ tabel. Jadi jika $\mathrm{t}$ hitung $<\mathrm{t}$ tabel, maka Ho diterima dan jika t hitung $>\mathrm{t}$ tabel, maka Ho ditolak. Selain itu dengan menggunakan tingkat probabilitas, dimana jika probabilitas $<0.05$, maka Ho ditolak.

\section{Hasil Penelitian dan Pembahasan}

1. Regresi Linear Berganda

Tabel 1. Hasil Regresi Linear Berganda

\begin{tabular}{|c|c|c|}
\hline \multirow{2}{*}{ MODEL } & \multicolumn{2}{|c|}{$\begin{array}{c}\text { UNSTANDARDIZED } \\
\text { COEFFICIENTS }\end{array}$} \\
\cline { 2 - 3 } & \multirow{3}{*}{ B } & STD. ERROR \\
\hline (CONSTANT) & 0.245 & 0.075 \\
\hline KONSERVATISME & 0.053 & 0.009 \\
\hline DIVIDEND PAYOUT RATIO & 0.285 & 0.080 \\
\hline TINGKAT LIKUIDITAS ASET & 0.015 & 0.102 \\
\hline LEVERAGE & -0.044 & 0.033 \\
\hline
\end{tabular}

a. Dependent Variable: Harga Saham

(Sumber: Hasil Olah SPSS, 2018)

Berdasarkan tabel 1, maka persamaan regresi liniear berganda dalam penelitian ini adalah sebagai berikut.

$Y=0,245+0,053 X_{1}+0,285 X_{2}+0,015 X_{3}-0,044 X_{4}$

a. Nilai konstanta bernilai positif yakni sebesar 0,245 dengan nilai signifikan sebesar 0,001 . Hal ini menunjukkan bahwa adanya hubungan positif antara variabel konservatisme, dividend payout ratio, tingkat likuiditas aset, dan leverage $\left(\mathrm{X}_{1}, \mathrm{X}_{2}\right.$, $\mathrm{X}_{3}$, dan $\mathrm{X}_{4}$ ) terhadap harga saham perusahaan manufaktur. Jika variabel-variabel independen tersebut mengalami kenaikan dalam satu satuan maka harga saham juga akan mengalami kenaikan sebesar 0,245 kali.

b. Nilai konservatisme $\left(\mathrm{X}_{1}\right)$ sebesar 0,053. Nilai parameter atau koefisien regresi ini menunjukkan bahwa jika variabel konservatisme meningkat 1 kali, maka harga saham perusahaan manufaktur akan mengalami kenaikan sebesar 0,053 kali dengan asumsi variabel lain tetap. 
c. Nilai dividend payout ratio $\left(\mathrm{X}_{2}\right)$ sebesar 0,285 . Nilai parameter atau koefisien regresi ini menunjukkan bahwa jika variabel dividend payout ratio meningkat 1 kali, maka harga saham perusahaan manufaktur akan mengalami kenaikan sebesar 0,285 kali dengan asumsi variabel lain tetap.

d. Nilai tingkat likuiditas aset $\left(\mathrm{X}_{3}\right)$ sebesar 0,015 . Nilai parameter atau koefisien regresi ini menunjukkan bahwa jika variabel tingkat likuiditas aset meningkat 1 kali, maka harga saham perusahaan manufaktur akan mengalami kenaikan sebesar 0,015 kali dengan asumsi variabel lain tetap.

e. Nilai leverage $\left(\mathrm{X}_{4}\right)$ sebesar $-0,044$. Nilai parameter atau koefisien regresi ini menunjukkan bahwa jika variabel leverage meningkat 1 kali, maka harga saham perusahaan manufaktur akan mengalami penurunan sebesar 0,044 kali dengan asumsi variabel lain tetap.

\section{Uji Statistik Deskriptif}

Tabel 2. Statistik Deskriptif

\begin{tabular}{|c|c|c|c|c|c|}
\hline & N & MINIMUM & MAXIMUM & MEAN & $\begin{array}{c}\text { STD. } \\
\text { DEVIATION }\end{array}$ \\
\hline KONSERVATISME & 530 & 0.01 & 45.56 & 3.0432 & 5.16268 \\
\hline $\begin{array}{c}\text { DIVIDEND } \\
\text { PAYOUT RATIO }\end{array}$ & 530 & 0.00 & 9.13 & 0.2871 & 0.60543 \\
\hline $\begin{array}{c}\text { TINGKAT } \\
\text { LIKUIDITAS ASET }\end{array}$ & 530 & 0.00 & 7.48 & 0.1283 & 0.47636 \\
\hline LEVERAGE & 530 & 0.00 & 11.25 & 1.2869 & 1.48493 \\
\hline HARGA SAHAM & 530 & 0.01 & 11.14 & 0.4330 & 1.11082 \\
\hline
\end{tabular}

(Sumber: Hasil Olah SPSS, 2018)

\section{Uji Normalitas}

Pada tabel di bawah ini akan disajikan tabel non parametic tests untuk menguji apakah data dalam penelitian ini berdistribusi normal atau tidak.

Tabel 3. Uji Normalitas

\begin{tabular}{|c|c|}
\hline & $\begin{array}{c}\text { UNSTANDARDIZED } \\
\text { RESIDUAL }\end{array}$ \\
\hline $\mathrm{N}$ & 530 \\
\hline NORMAL PARAMETERS - MEAN & 0.0000000 \\
NORMAL PARAMETERS - STD. & 1.05637963 \\
DEVIATION & 0.309 \\
\hline TEST STATISTIC & 0.000 \\
\hline ASYMP. SIG (2-tailed) & \\
\hline
\end{tabular}

(Sumber: Hasil Olah SPSS, 2018)

Berdasarkan tabel 3, dapat dilihat bahwa data untuk variabel dependen dan independen, tidak berdistribusi normal atau tidak memenuhi asumsi normalitas. Hal ini dapat dilihat dari nilai signifikan untuk kelima variabel tersebut lebih kecil dari nilai signifikansi $0,05(\alpha=5 \%)$. Meskipun nilai signifikan tidak lebih besar dari nilai signifikansi sehingga data tidak berdistribusi normal, akan tetapi terdapat sebuah teori yang menyatakan data tersebut dapat dikatakan berdistribusi normal jika sampel dalam penelitian tersebut mencapai 30 sampel atau lebih. Teori ini disebut dengan Central Limit Theorem (Teori Limit Pusat) yang diperkenalkan pertama kalinya oleh Pierre Simon Laplace (Spiegel, 1999). Teori ini 
menyatakan bahwa kurva distribusi sampling (untuk ukuran sampel 30 atau lebih) akan berpusat pada nilai parameter populasi dan akan memiliki semua sifat-sifat distribusi normal. Kegunaan teorema terletak pada kesederhanaan definisinya. Teori juga menyatakan bahwa jika beberapa kondisi tertentu terpenuhi, maka distribusi rata-rata dari sejumlah variabel independen mendekati distribusi normal dengan jumlah sampel mendekati tak terhingga. Dengan kata lain, tidak diperlukan informasi yang banyak tentang distribusi aktual variabel, asalkan ada cukup sampel dari mereka, jumlah mereka dapat didistribusikan secara normal.

4. Uji Heteroskedastisitas

Pada tabel di bawah ini akan disajikan hasil dari uji heterokedastisitas adalah sebagai berikut.

Tabel 4. Uji Heteroskedastisitas

\begin{tabular}{|c|c|c|c|c|c|}
\hline \multirow{2}{*}{ MODEL } & \multicolumn{2}{|c|}{$\begin{array}{c}\text { UNSTANDARDIZED } \\
\text { COEFFICIENTS }\end{array}$} & $\begin{array}{c}\text { STANDARDIZED } \\
\text { COEFFICIENTS }\end{array}$ & \multirow{2}{*}{ T } & Sig. \\
\cline { 2 - 6 } & B & $\begin{array}{c}\text { STD. } \\
\text { ERROR }\end{array}$ & BETA & \\
\hline (CONSTANT) & -0.044 & 0.475 & & -0.092 & 0.927 \\
\hline KONSERVATISME & 0.032 & 0.019 & 0.152 & 1.716 & 0.087 \\
\hline DIVIDEND & 0.171 & 0.124 & 0.105 & 1.376 & 0.170 \\
\hline PAYOUT RATIO & 0.086 & 1.188 & 0.009 & 0.072 & 0.943 \\
\hline TINGINGT & 0.013 & 0.150 & 0.010 & 0.085 & 0.932 \\
\hline LEVITERAGE & & & & & \\
\hline
\end{tabular}

a. Dependent Variable: RES2

(Sumber: Hasil Olah SPSS, 2018)

Pada tabel 4, hasil dari uji heteroskedastisitas menunjukkan bahwa semua variabel independen tidak terdapat gejala heterokedastisitas. Hal ini dapat dilihat dari nilai signifikan untuk semua variabel independen dalam penelitian ini yang lebih besar dari nilai signifikansi $0,05(\alpha=5 \%)$. Dengan demikian, variabel independen dalam penelitian ini tidak terdapat heterokedastitas.

\section{Uji Multikolinearitas}

Pada tabel di bawah ini akan disajikan hasil dari uji multikoloniearitas dalam penelitian ini sebagai berikut.

\begin{tabular}{|c|c|c|c|c|c|}
\hline \multirow{2}{*}{ MODEL } & \multicolumn{2}{|c|}{$\begin{array}{c}\text { UNSTANDARDIZED } \\
\text { COEFFICIENTS }\end{array}$} & \multirow{2}{*}{$\begin{array}{c}\text { STANDARDIZED } \\
\text { COEFFICIENTS } \\
\text { BETA }\end{array}$} & \multicolumn{2}{|c|}{$\begin{array}{c}\text { COLLINEARITY } \\
\text { STATISTICS }\end{array}$} \\
\hline & B & $\begin{array}{c}\text { STD. } \\
\text { ERROR }\end{array}$ & & TOLERANCE & VIF \\
\hline (CONSTANT) & 0.290 & 0.060 & & & \\
\hline KONSERVATISME & 0.051 & 0.008 & 0.286 & 0.990 & 1.010 \\
\hline $\begin{array}{c}\text { DIVIDEND PAYOUT } \\
\text { RATIO }\end{array}$ & 0.365 & 0.065 & 0.238 & 0.992 & 1.008 \\
\hline $\begin{array}{c}\text { TINGKAT } \\
\text { LIKUIDITAS ASET }\end{array}$ & -0.019 & 0.082 & -0.010 & 0.994 & 1.006 \\
\hline LEVERAGE & -0.034 & 0.026 & -0.055 & 0.992 & 1.008 \\
\hline
\end{tabular}

(Sumber: Hasil Olah SPSS, 2018) 
Pada tabel 5, dapat dilihat bahwa nilai standard error untuk semua variabel independen dalam penelitian yakni variabel konservatisme, dividend payout ratio, tingkat likuiditas aset, dan leverage semuanya kurang dari nilai satu. Hal ini berarti bahwa tidak adanya multikolinearitas dalam penelitian ini. Hal ini didukung dengan melihat nilai VIF dan tolerance pada tabel tersebut yakni nilai VIF untuk semua variabel independen kurang dari nilai 10 dan untuk nilai tolerance lebih dari nilai 0,01 . Dengan demikian, dapat dinyatakan bahwa adanya hubungan yang linear atau hubungan ynag kuat antara satu variabel bebas (independen) dengan variabel bebas yang lainnya karena telah memenuhi syarat multikolinearitas.

\section{Uji Parsial (Uji t)}

Uji statistik (uji t) ini dilakukan untuk mengetahui pengaruh dari variabel independen secara individual terhadap variabel dependen yakni harga saham. Pada tabel di bawah ini akan disajikan hasil dari uji statistik (uji t) yang telah dilakukan.

\begin{tabular}{|c|c|c|c|c|c|}
\hline \multirow{3}{*}{ MODEL } & $\begin{array}{c}\text { UNSTANDARDIZED } \\
\text { COEFFICIENTS }\end{array}$ & $\begin{array}{c}\text { STANDARDIZED } \\
\text { COEFFICIENTS }\end{array}$ & \multirow{2}{*}{ S } & \multirow{2}{*}{ Sig. } \\
\cline { 2 - 6 } & B & $\begin{array}{c}\text { STD. } \\
\text { ERROR }\end{array}$ & BETA & & \\
\hline (CONSTANT) & 0.245 & 0.075 & & 3.272 & 0.001 \\
\hline KONSERVATISME & 0.053 & 0.009 & 0.245 & 5.581 & 0.000 \\
\hline $\begin{array}{c}\text { DIVIDEND } \\
\text { PAYOUT RATIO }\end{array}$ & 0.285 & 0.080 & 0.155 & 3.549 & 0.000 \\
\hline $\begin{array}{c}\text { TINGKAT } \\
\text { LIKUIDITAS ASET }\end{array}$ & 0.015 & 0.102 & -0.007 & 0.149 & 0.882 \\
\hline LEVERAGE & -0.044 & 0.033 & -0.058 & -1.335 & 0.182 \\
\hline
\end{tabular}

a. Dependent Variable: Harga Saham

(Sumber: Hasil Olah SPSS, 2018)

Berdasarkan tabel 6, diperoleh hasil untuk uji parsial (uji t) adalah sebagai berikut.

a. Hasil uji statistik variabel konservatisme $\left(\mathrm{X}_{1}\right)$, t hitung dan nilai signifikan (Sig.) diperoleh angka sebesar 5,581 $>\mathrm{t}$ tabel 1,98373 dan sig. hitung $0,000<0,05(\alpha=5 \%)$. Dengan demikian konservatisme $\left(\mathrm{X}_{1}\right)$ berpengaruh signifikan terhadap harga saham perusahaan manufaktur (Y) dan besarnya nilai koefisien pengaruh langsung konservatisme terhadap harga saham perusahaan manufaktur adalah sebesar 0,245.

b. Hasil uji statistik variabel dividend payout ratio $\left(\mathrm{X}_{2}\right)$, t hitung dan nilai signifikan (Sig.) diperoleh angka sebesar 3,549 > t tabel 1,98373 dan sig. hitung 0,000<0,05 $(\alpha=5 \%)$. Dengan demikian dividend payout ratio $\left(\mathrm{X}_{2}\right)$ berpengaruh signifikan terhadap harga saham perusahaan manufaktur (Y) dan besarnya nilai koefisien pengaruh langsung dividend payout ratio terhadap harga saham perusahaan manufaktur adalah sebesar 0,155 .

c. Hasil uji statistik variabel tingkat likuiditas aset $\left(\mathrm{X}_{3}\right), \mathrm{t}$ hitung dan nilai signifikan (Sig.) diperoleh angka sebesar 0,149 < t tabel 1,98373 dan sig. hitung 0,882 >0,05 $(\alpha=5 \%)$. Dengan demikian tingkat likuiditas aset $\left(X_{3}\right)$ tidak berpengaruh signifikan terhadap harga saham perusahaan manufaktur (Y) dan besarnya nilai koefisien pengaruh langsung tingkat likuiditas aset terhadap harga saham perusahaan manufaktur adalah sebesar -0.007 .

d. Hasil uji statistik variabel leverage $\left(\mathrm{X}_{4}\right)$, t hitung dan nilai signifikan (Sig.) diperoleh angka sebesar $-1,335<\mathrm{t}$ tabel 1,98373 dan sig. hitung $0,182>0,05(\alpha=5 \%)$. Dengan demikian variabel leverage $\left(\mathrm{X}_{4}\right)$ tidak berpengaruh signifikan terhadap harga saham perusahaan manufaktur $(\mathrm{Y})$ dan besarnya nilai koefisien pengaruh langsung leverage terhadap harga saham perusahaan manufaktur adalah sebesar $-0,058$. 


\section{Pembahasan}

Berdasarkan hasil penelitian dan pengujian parsial (uji t) yang telah dilakukan diketahui bahwa:

1. Hasil penelitian menunjukkan bahwa variabel konservatisme $\left(\mathrm{X}_{1}\right)$, $\mathrm{t}$ hitung dan nilai signifikan (Sig.) diperoleh angka sebesar 6,750 >t tabel 1,98373 dan sig. hitung 0,000 $<0,05(\alpha=5 \%)$. Dengan demikian konservatisme $\left(\mathrm{X}_{1}\right)$ berpengaruh signifikan terhadap harga saham perusahaan manufaktur (Y). Hasil penelitian ini sejalan dengan hasil penelitian yang dilakukan oleh Lyimo (2014), Shafiei dan Javaheri (2016). Perusahaan yang menerapkan prinsip konservatisme dengan tidak terburu-buru mengakui aset dan laba, tetapi mengakui biaya dan rugi di awal membuat para investor tertarik untuk membeli saham perusahaan tersebut dikarenakan dengan begitu perusahaan mengambil reaksi yang hati-hati dalam menghadapi ketidakpastian dan risiko yang akan dihadapi dalam lingkungan bisnis, sehingga perusahaan dapat meminimalkan risiko yang dapat dialami oleh perusahaan dalam menjalankan kegiatan operasionalnya. Konservatisme juga dapat meningkatkan kualitas dari laporan keuangan perusahaan tersebut. Laporan keuangan yang baik dan audit report yang cepat membuat perusahaan dapat memberikan sinyal atau berita bagus kepada para calon investor maupun para investor yang sudah membeli saham perusahaan tersebut.

2. Hasil penelitian menunjukkan bahwa dividend payout ratio $\left(\mathrm{X}_{2}\right)$, t hitung dan nilai signifikan (Sig.) diperoleh angka sebesar 5,627 < t tabel 1,98373 dan sig. hitung 0,000 $>0,05(\alpha=5 \%)$. Dengan demikian dividend payout ratio $\left(\mathrm{X}_{2}\right)$ berpengaruh signifikan terhadap harga saham perusahaan manufaktur (Y). Hasil penelitian ini sejalan dengan penelitian yang dilakukan oleh Wijaya dan Suarjaya (2017). Dengan laba atau profit yang didapat perusahaan, pada umumnya perusahaan akan membagikan dividen kepada para pemegang saham. Dividen yang diberikan perusahaan kepada para pemegang saham dapat menjadi sinyal atau berita bagus bagi para investor dikarenakan dividen merupakan salah satu daya tarik para investor untuk membeli saham perusahaan tersebut selain capital gain.

3. Hasil penelitian menunjukkan bahwa variabel tingkat likuiditas aset $\left(\mathrm{X}_{3}\right)$, $\mathrm{t}$ hitung dan nilai signifikan (Sig.) diperoleh angka sebesar 0,230 < t tabel 1,98373 dan nilai sig. hitung 0,818 > $0,05(\alpha=5 \%)$. Dengan demikian tingkat likuiditas aset $\left(X_{3}\right)$ tidak berpengaruh signifikan terhadap harga saham perusahaan manufaktur (Y). Dengan banyaknya perusahaan yang tidak memiliki aset yang likuid dikarenakan nilai kas dan setara kas perusahaan yang terlampau kecil dibandingkan dengan total asetnya sehingga dapat meningkatkan penggunaan biaya modal dan meningkatkan risiko yang dihadapi perusahaan. Rendahnya aset perusahaan yang likuid membuat perusahaan tidak dapat memanfaatkan aset-aset yang dimiliki untuk menjadi tambahan pendanaan bagi kegiatan operasionalnya. Hasil penelitian ini sejalan dengan hasil penelitian yang dilakukan oleh Sukoco (2013), yang menyatakan bahwa likuiditas tidak berpengaruh terhadap nilai perusahaan.

4. Hasil penelitian menunjukkan bahwa variabel leverage dengan proksi debt to equity ratio/DER $\left(\mathrm{X}_{4}\right)$, $\mathrm{t}$ hitung dan nilai signifikan (Sig.) yang diperoleh angka sebesar 1,296 < $\mathrm{t}$ tabel 1,98373 dan nilai sig. hitung 0,393 >0,05 $(\alpha=5 \%)$. Dengan demikian leverage $\left(\mathrm{X}_{4}\right)$ tidak berpengaruh signifikan terhadap harga saham perusahaan manufaktur (Y). Hasil penelitian ini sejalan dengan penelitian yang dilakukan oleh Putra dan Yaniartha (2014), dan Musfitria (2016), yang menyatakan bahwa leverage memiliki hubungan negatif dan tidak memiliki pengaruh signifikan terhadap harga saham. Perusahaan-perusahaan yang memiliki hutang yang besar akan berdampak pada kemampuan perusahaan dalam menghasilkan laba atau profit, apalagi disaat hutang perusahaan lebih besar daripada modal perusahaan tersebut sehingga meningkatkan risiko yang dihadapi perusahaan. Hal itu akan berdampak pada pandangan para investor bahwa perusahaan tersebut sedang dalam keadaan yang kurang baik dan mengakibatkan para investor menjadi ragu untuk membeli saham perusahaan tersebut sehingga tidak meningkatkan nilai perusahaan.

\section{Penutup \\ Kesimpulan} sebagai berikut.

Berdasarkan hasil penelitian dan pembahasan, maka kesimpulan dalam penelitian ini adalah

1. Konservatisme berpengaruh signifikan terhadap harga saham perusahaan manufaktur yang terdaftar di Bursa Efek Indonesia periode tahun 2013-2017. 
2. Dividend Payout Ratio (DPR) berpengaruh signifikan terhadap harga saham perusahaan manufaktur yang terdaftar di Bursa Efek Indonesia periode tahun 2013-2017.

3. Tingkat Likuiditas Aset tidak berpengaruh signifikan terhadap harga saham perusahaan manufaktur yang terdaftar di Bursa Efek Indonesia periode tahun 2013-2017.

4. Leverage tidak berpengaruh signifikan terhadap harga saham perusahaan manufaktur yang terdaftar di Bursa Efek Indonesia periode tahun 2013-2017.

\section{Saran}

Berdasarkan hasil penelitian, pembahasan, dan kesimpulan dalam penelitian ini, maka saran yang dapat diberikan adalah sebagai berikut.

1. Bagi perusahaan, perlu memperhatikan konservatisme, dividend payout ratio, tingkat likuiditas aset, dan leverage sebagai indikator yang dapat mempengaruhi harga saham perusahaan manufaktur yang terdaftar di Bursa Efek Indonesia.

2. Bagi para investor, dapat menilai konservatisme dan tingkat pembagian dividen kepada para pemegang saham sebagai bahan pertimbangan dalam pengambilan keputusan investasi, perusahaan mana yang akan dibeli sahamnya.

3. Bagi peneliti selanjutnya, karena pada penelitian ini menggunakan data terakhir tahun 2017 , peneliti selanjutnya diharapkan menggunakan data laporan keuangan perusahaan yang terbaru yaitu data laporan keuangan tahun 2018 dan bisa menggunakan variabel intervening atau moderating dalam penelitian ataupun hendaknya menambah variabel dan sampel penelitian.

\section{DAFTAR PUSTAKA}

Anjarwati, K., Chabachib, M., \& Demi, P. 2016. Pengaruh Profitabilitas, Size, dan Likuiditas Terhadap Nilai Perusahaan dengan Struktur Modal sebagai Variabel Intervening. Diponegoro Journal of Finance.

Brigham, E. F., \& Houston J. F. 2011. Dasar - Dasar Manajemen Keuangan. Salemba Empat. Jakarta.

Chatterjee, Chanchal. 2015. Anomalus Price Behaviour Around Open Market Stock Repurchase Announcements in India. International Management Institute Kolkata, 40(4), 435-443.

En, T. K., \& Rusli L. 2011. Analisis Likuiditas Saham serta Pengaruhnya terhadap Harga Saham Perusahaan Manufaktur yang Terdaftar di Bursa Efek Indonesia. Jurnal Bisnis Manajemen dan Ekonomi, 10(2).

Ernawati, D., \& Widyawati. 2015. Pengaruh Profitabilitas, Leverage, dan Ukuran Perusahaan Terhadap Nilai Perusahaan. Jurnal Ilmu dan Riset Akuntansi, 4(4).

Falani, Achmad, 2013. Analisis Laporan Keuangan Perusahaan sebagai Dasar Pengambilan Keputusan Investasi Saham Berbasis Du Pont System dan Fuzzy Logic. Ejournal Narotama, 18(1), 1-7.

Fama, E., 1970. Efficient Capital Markets: A Review of Theory and Empirical Work. Journal of Finance, 25(2).

Gitman, Lawrence. 2009. Principles of Manajerial Finance. United States, Pearson Addison Wesley.

Givoly, D., \& Hayn, C. 2002. Rising Conservatism: Implication for Financial Analysis. Financial Analists Journal, 56-74.

Gursida, Hari. 2015. Pengaruh Profitabilitas dan Leverage Terhadap Harga Saham Perusahaan yang Terdaftar di Bursa Efek Indonesia. Universitas Pakuan.

Hery. 2015. Analisis Laporan Keuangan. Penerbit CAPS (Center for Academy Publishing Service). Yogyakarta.

Jensen and Meckling. 1976. The Theory of The Firm: Managerial Behaviour, Agency Cost, and Ownership Structure. Journal of Financial and Economic, 302-360.

Kusumadewi, D., \& Sudiartha, G. 2016. Pengaruh Likuiditas, Dividend Payout Ratio, Kesempatan Investasi dan Leverage Terhadap Price Earning Ratio. E-Jurnal Manajemen Unud, 5(9).

Lyimo, G. 2014. Conditional Conservatism and its Effect on Earnings Quality and Stock Prices in Indian Capital Market. European Journal of Business and Management, 2222-2839.

Munawir, S. 2002. Analisa Laporan Keuangan. Edisi Keempat. Yogyakarta: Liberty.

Musfitria, Anessa. 2016. Pengaruh Dividen dan Leverage Terhadap perkiraan Harga Saham (Studi pada Perusahaan yang tercatat di Bursa Efek Indonesia Periode 2006 - 2011). International Multidisciplinary Conference, 9-16. 
Novalia, F., \& Nindito, M. 2016. Pengaruh Konservatisme Akuntansi dan Economic Value Added Terhadap Penilaian Ekuitas Perusahaan. Jurnal Ilmiah Wahana Akuntansi, 11(2).

Nugraha, R. D., \& Sudaryanto, B. 2016. Analisis Pengaruh DPR, DER, ROE, dan TATO Terhadap Harga Saham (Studi Kasus pada Perusahaan Industri Dasar dan Kimia yang Terdaftar di BEI Periode 2010-2014). Diponegoro Journal of Management, 5(4), 2337-3792.

Putra, G. S., \& Yaniartha, D. 2014. Pengaruh Leverage, Inflasi, dan PDB pada Harga Saham Perusahaan Asuransi. E-Jurnal Akuntansi Universitas Udayana, 9(2), 449-464.

Ross, S. A. 1973. The Economic Theory of Agency: The Principal's Problem. The American Economic Review, 63(2), 134-139.

Ross, S. A. 1977. The Determination of Financial Structure: The Incentive Signalling Approach. Journal of Economics, 23-40.

Sartono, Agus. 2008. Manajemen Keuangan Teori dan Aplikasi. Edisi Empat. Yogyakarta: BPFE.

Shafiei, M., \& Javaheri, B. 2016. Investigating the Relationship between Accounting Conservatism on Earnings Quality and Stock Price in Corporations of Accepted in Tehran Stock Exchange. International Journal of Humanities and Cultural Studies, 2356-5926.

Spiegel, M. R. 1999. Transformasi Laplace. Jakarta: Erlangga.

Sukoco, Heri. 2013. Analisis Pengaruh Debt to Equity Ratio, Profitabilitas, Firm Size, dan Likuiditas Terhadap Nilai Perusahaan. Jurnal Fakultas Ekonomi dan Bisnis Universitas Diponegoro.

Sunyoto, Danang. 2012. Analisis Regresi dan Uji Hipotesis. Yogyakarta: Media Pressindo.

Susanto, B., \& Ramadhani, T. 2016. Faktor-Faktor yang Memengaruhi Konservtaisme (Studi Kasus pada Perusahaan Manufaktur yang Terdaftar di Bursa Efek Indonesia Periode 2010-2014). Jurnal Bisnis dan Ekonomi, 23(2).

Tuwentina, P., \& Wirama, D. G. 2017. Pengaruh Konservatisme Akuntansi dan Good Corporate Governance pada Kualitas Laba. E-Journal Akuntansi Universitas Udayana, 8(2), 2302-8556.

Wijaya, G. O., \& Suarjaya, A. G. 2017. Pengaruh EVA, ROE dan DPR Terhadap Harga Saham Perusahaan Manufaktur di BEI. E-Jurnal Manajemen Unud, 6(9), 2302-8912. 